\title{
POLITICAL PARTIES IN POWER AND U.S. ECONOMIC PERFORMANCE
}

\author{
William T. Chittenden, Texas State University
}

\begin{abstract}
This study examines the simultaneous interaction between political control of the White House and both chambers of Congress and the impact of those combinations on various measures of economic activity in the U.S. Past economic growth is not significantly different under Republican and Democratic presidential administrations. Nor does the party that controls the House of Representatives appear to have a significant impact on economic growth. However, growth has been strongest when Republicans control the Senate. Non-farm payrolls and industrial production grow faster under Democratic Presidents, while higher inflation and unemployment are generally observed when Democrats control the Senate or House. Republican Presidents are in office for a significantly greater number of months when the economy is in a recession. The same is true when Democrats are in charge of the Senate or House. The U.S. economy appears to have the strongest performance under the combination of a Democratic President with a Republican controlled Senate and House, and the weakest economic performance is generally under a Republican President with a Senate controlled by Democrats and a Republican controlled House.
\end{abstract}

JEL: D72, E32, N12

KEYWORDS: Political Business Cycle, Leading Indicators, Economic History

\section{INTRODUCTION}

$\mathrm{T}$

The phrase "It's the economy, stupid" was coined by James Carville during the 1992 presidential race to try and tie President G.H.W. Bush's re-election chances to the 1990-1991 recession (Brown, 1992). Right or wrong, U.S. presidents have been given credit for strong economies and the blame for economic weakness. Johnson, Chittenden, and Jensen (1999), among others, have examined the relationship between stock and bond returns and which political party controls the White House. Others, like Hibbs (1977) and Blinder and Watson (2016) have compared macroeconomic performance in a similar manner. Beyer, Jensen, and Johnson (2006) consider the impact of political gridlock. This paper expands on previous research by separately comparing the changes in macroeconomic variables across which political party controls the presidency, the Senate, and the House of Representatives (the House). In addition, the simultaneous interaction between political control of the White House, the Senate, and the House is considered. The remainder of the paper is organized as follows. In the next section, the literature on economic performance under different political parties is surveyed. The data and methodology used in the study are discussed next. The results and discussion, including limitations of the study, are presented in the following section. The paper closes with some concluding comments and suggestions for future research.

\section{LITERATURE REVIEW}

Numerous studies have examined the relationship between the political party of the President with the performance of financial assets. Johnson, Chittenden, and Jensen (1999) find that small-cap stock returns are higher during Democratic presidential administrations while bond returns are higher during Republican 
administrations. Santa-Clara and Valkanov (2003), Liston, Chong, and Bayram (2014), and others, report comparable findings. Abidin, Old, and Martin (2010) observe analogous effects in New Zealand. However, Jones and Banning (2009) find no significant difference in stock returns during Democratic and Republican administrations. Sy and Al Zaman (2011) suggest higher stock returns during Democratic administrations can be attributed to higher market and default risk premiums. Herbst and Slinkman (1984) conclude that the stock market follows a cycle that corresponds to U.S. presidential elections. Beyer, Jensen, and Johnson (2008), Wong and McAleer (2009), and Kräussl, Lucas, Rijsbergen, van der Sluis, and Vrugt (2014) come to similar conclusions. Sturm (2016) finds that firms' book-to-market ratios are related to the presidential election cycle. Belo, Gala, and Li (2013) conclude that the presidential cycle is strongest for firms with high exposure to government spending. Lamb, Ma, Pace, and Kennedy (1997) state that average daily stock market returns "when Congress is not meeting are almost thirteen times greater than when Congress is in session." Liston, et al. (2014) find that investor sentiment is higher during Democratic administrations while Adjei and Adjei (2017) find that investor sentiment starts low and rises during Democratic administrations and starts high but falls during Republican administrations. See Wisniewski (2016) for a more extensive review of the literature that examines politics and stock returns.

Rather than focusing on the financial markets, others have examined the impact of political party control and the performance of macroeconomic variables. Fair $(1978,1982,1988)$ models how macroeconomic variables can predict presidential outcomes. Blinder and Watson (2016) find that real GDP grew 1.79 percentage points faster under Democratic administrations compared to Republican administrations. They attribute the positive difference in economic growth during Democratic administrations to favorable oil price shocks, higher growth in defense spending, and higher productivity shocks compared to Republican administrations. Most of the literature in this area focuses exclusively on the political party of the president. Some, like Beyer, Jensen, and Johnson (2006) and Blinder and Watson (2016) include measures for which political party controls Congress. Beyer, et al. (2006) conclude that stock market returns are generally higher "during periods of political harmony" and poor during periods of gridlock. Political harmony is defined as when the same political party controls the presidency, the Senate, and the House. Blinder and Watson (2016) take a similar approach. These studies treat Congress as a single entity rather than two distinct chambers. This paper extends the current literature by examining the individual and joint impact of which political party controls the presidency, the Senate, and the House.

\section{DATA AND METHODOLOGY}

This study uses quarterly and monthly data from 1977 through 2016. This period is chosen for several reasons. During this period, all presidents served their entire term. Extending to a longer period would necessitate including the time periods of political uncertainty after the deaths of presidents Franklin Roosevelt and John Kennedy and the resignation of Richard Nixon. In addition, the time period is long enough that there are a large number of both quarterly and monthly observations, but not so long that there are major structural changes (for example, the collapse of Bretton Woods or the establishment of the Treasury-Fed Accord.) Also, this period coincidently is evenly split between Democratic and Republican presidential administrations. Quarterly data for 160 quarters was obtained from FRED (Federal Reserve Economic Data) at the Federal Reserve Bank of St. Louis. This data includes the annualized percent change from the preceding quarter in real GDP (seasonally adjusted), annualized percent change from the quarter one year prior in real GDP (seasonally adjusted), the annualized percent change in Nonfarm Business Sector Real Output, and the annualized percent change in Business Sector Real Output. Monthly data for 480 months comes from two sources. Monthly data for the Coincident Economic Index (CEI) were obtained from The Conference Board. Monthly data for Total Nonfarm Payrolls (TNFP), Industrial Production (INDPRO), the Consumer Price Index for All Urban Consumers: All Items (CPI), the Producer Price Index for All Commodities (PPI), the unemployment rate, and the NBER based Recession Indicator for the United States from the Period following the Peak through the Trough were retrieved from FRED. The monthly percent change for the CEI, TNFP, INDPRO, CPI, and PPI was calculated as: 
$\% \Delta X=\frac{X_{t}}{X_{t-1}}-1$

where $\mathrm{X}$ is the variable and $\mathrm{t}$ is the time period. The parametric Welch's (1951) unequal variances t-test is used to compare the means of the variables during Democratic and Republican control. Ruxton (2006) states "the unequal variance t-test performs as well as, or better than, the Student's t-test in terms of control of both Type I and Type II error rates whenever the underlying distributions are normal." In addition, the non-parametric Mann-Whitney test is used to compare the means. Conover (1999) demonstrates that this test is consistent and unbiased regardless if the underlying data are normally distributed or not. The related one-way chi square approximation is used to evaluate the difference in the number of months of recession under each political party.

\section{RESULTS AND DISCUSSION}

During the period examined, January 1977 through December 2016, Democrats and Republicans each controlled the presidency fifty percent of the time. As shown in Table 1, Democrats and Republicans each held the White House for 80 quarters (240 months). Democrats had a majority in the Senate for 86 quarters (259 months) versus 74 quarters (221 months) for the Republicans. In the House, Democrats led for 88 quarters (264 months) while Republicans had control for 72 quarters (216 months).

Table 1: Political Party in Control 1977-2016

\begin{tabular}{l|ccc}
\hline \multicolumn{4}{l}{ Quarters } \\
\hline & President & Senate & House \\
\hline Democrat & 80 & 86 & 88 \\
Republican & 80 & 74 & 72 \\
Total & 160 & 160 & 160 \\
\hline Months & President & Senate & House \\
\hline \multicolumn{4}{l}{} \\
\hline Democrat & 240 & 259 & 264 \\
Republican & 240 & 221 & 216 \\
Total & 480 & 480 & 480 \\
\hline
\end{tabular}

This table shows the number of quarters and months that Democrats and Republicans were in control of the presidency, the Senate, and the House of Representatives. Note that between January and May 2001, the Senate was split with 50 Democrats and 50 Republicans and the Republican Vice-President cast any tie-breaking vote. For these months, Republicans were counted as having control of the Senate. In June 2001, a Republican Senator switched to Independent and caucused with the Democrats, giving Democrats the majority.

Blinder and Watson (2016) found that GDP grew faster under Democratic presidential administrations versus Republican administrations between 1949 - 2012. They observe "that a sizeable share of the overall D-R gap comes from the Truman and Kennedy-Johnson years." During the forty years examined in this study, economic growth is also higher during Democratic presidencies as compared to Republican presidencies. As shown in Table 2, GDP growth (measured as the annualized percent change from the previous quarter) was on average $0.3175 \%$ faster each year under a Democratic president. When GDP is measured as the percent change from one year prior, the difference falls to $0.1287 \%$. In both cases, the difference is not statistically significant. When economic growth is measured as the percent change in Nonfarm Business Sector Real Output (percent change in Business Sector Real Output), the difference is $0.1727 \%(0.1707 \%)$ in favor of the Democrats. As with GDP, these differences are not statistically significant. Generally speaking, economic growth is not significantly different under Democratic presidents than Republican presidents. 
Table 2: Mean Difference Analysis for Economic Growth by Presidential Political Party

\begin{tabular}{l|ccccc}
\hline & Party & Mean & Difference & \\
\hline Qtrly Real GDP, $\% \Delta$ from Preceding Period & Democratic & $2.9600 \%$ & $0.3175 \%$ & Prob $>|t|$ & 0.5183 \\
& Republican & $2.6425 \%$ & & Prob $>|\mathrm{Z}|$ & 0.9823 \\
Qtrly Real GDP, $\% \Delta$ from Qtr. One Year Ago & Democratic & $2.8487 \%$ & $0.1287 \%$ & $\operatorname{Prob}>|\mathrm{t}|$ & 0.6964 \\
& Republican & $2.7200 \%$ & & Prob $>|\mathrm{Z}|$ & 0.4547 \\
$\% \Delta$ in Nonfarm Business Sector Real Output & Democratic & $0.8451 \%$ & $0.1727 \%$ & Prob $>|\mathrm{t}|$ & 0.2535 \\
& Republican & $0.6724 \%$ & & Prob $>|\mathrm{Z}|$ & 0.3983 \\
$\% \Delta$ in Business Sector Real Output & Democratic & $0.8507 \%$ & $0.1707 \%$ & Prob $>|t|$ & 0.2758 \\
& Republican & $0.6800 \%$ & & Prob $>|\mathrm{Z}|$ & 0.4885
\end{tabular}

This table shows mean difference analysis for GDP growth measured as the annualized percent change from the previous quarter, GDP growth measured as the percent change from one year prior, the percent change in Nonfarm Business Sector Real Output and the percent change in Business Sector Real Output. The last column reports the $p$-value associated with a two-tailed test for the parametric $t$-test (Prob $>|t|)$ and the non-parametric Mann-Whitney test (Prob $>|Z|$ ) for differences in means. ***, **, and * indicate significance at the 1, 5 and 10 percent levels, respectively. The number of observations in each sample is the same number of quarters as indicated in Table 1.

When economic growth is compared to when Democrats versus Republicans control the Senate, growth is slower under Democratic Senates. As documented in Table 3, GDP growth (measured as the annualized percent change from the previous quarter) was $1.0335 \%$ faster on average each year under a Republican Senate. This difference is statistically significant at the $5 \%$ level using both the parametric t-test (Prob $>|t|)$ and the non-parametric Mann-Whitney test (Prob $>|\mathrm{Z}|)$. When GDP is measured as the percent change from one year prior, the Republican advantage increases to $1.1554 \%$, which is significant at the $1 \%$ level. Using the percent change in Nonfarm Business Sector Real Output (percent change in Business Sector Real Output) to compare economic activity, the difference is $0.3160 \%(0.3156 \%)$ in favor of the Republicans. These differences are statistically significant at the $5 \%$ level. Economic growth is stronger when the Senate is controlled by Republicans. The differences in economic growth based on the political party controlling the House is similar to the results found for the presidency. As shown in Table 4, economic growth is weaker when Democrats control the House, but these differences are not statistically significant. GDP growth (measured as the annualized

Table 3: Mean Difference Analysis for Economic Growth by Senate Political Party

\begin{tabular}{l|ccccc}
\hline & Party & Mean & Difference & \\
\hline Qtrly Real GDP, $\% \Delta$ from Preceding Period & Democratic & $2.3233 \%$ & $-1.0335 \%$ & Prob $>|\mathrm{t}|$ & $0.0328^{* *}$ \\
& Republican & $3.3568 \%$ & & Prob $>|\mathrm{Z}|$ & $0.0152^{* *}$ \\
Qtrly Real GDP, $\% \Delta$ from Qtr One Year Ago & Democratic & $2.2500 \%$ & $-1.1554 \%$ & $\operatorname{Prob}>|\mathrm{t}|$ & $0.0004^{* * *}$ \\
& Republican & $3.4054 \%$ & & Prob $>|\mathrm{Z}|$ & $0.0001^{* * *}$ \\
$\% \Delta$ in Nonfarm Business Sector Real Output & Democratic & $0.6171 \%$ & $-0.3160 \%$ & Prob $>|\mathrm{t}|$ & $0.0439^{* *}$ \\
& Republican & $0.9331 \%$ & & Prob $>|\mathrm{Z}|$ & $0.0295^{* *}$ \\
$\% \Delta$ in Business Sector Real Output & Democratic & $0.6180 \%$ & $-0.3156 \%$ & Prob $>|t|$ & $0.0392^{* *}$ \\
& Republican & $0.9336 \%$ & & Prob $>|\mathrm{Z}|$ & $0.0248^{* *}$
\end{tabular}

This table shows mean difference analysis for GDP growth measured as the annualized percent change from the previous quarter, GDP growth measured as the percent change from one year prior, the percent change in Nonfarm Business Sector Real Output and the percent change in Business Sector Real Output. The last column reports the $p$-value associated with a two-tailed test for the parametric $t$-test (Prob $>|t|)$ and the non-parametric Mann-Whitney test (Prob $>|Z|)$ for differences in means. ***, **, and * indicate significance at the 1, 5 and 10 percent levels, respectively. The number of observations in each sample is the same number of quarters as indicated in Table 1.

percent change from the previous quarter) was $0.1619 \%$ slower on average each year under a Democratic House. When GDP is measured as the percent change from one year prior, the difference is $0.2733 \%$ in 
favor of the Republicans. The difference in the percent change in Nonfarm Business Sector Real Output (percent change in Business Sector Real Output) is even smaller in magnitude. Although the differences are not statistically significant, economic growth is slightly stronger when Republicans control the House. In summary, economic growth is strongest when a Democrat is in the White House and when Republicans control the Senate or House.

Table 4: Mean Difference Analysis for Economic Growth by House Political Party

\begin{tabular}{l|ccccc}
\hline & Party & Mean & Difference & \\
\hline Qtrly Real GDP, $\% \Delta$ from Preceding Period & Democratic & $2.7284 \%$ & $-0.1619 \%$ & Prob $>|t|$ & 0.7294 \\
& Republican & $2.8903 \%$ & & Prob $>|\mathrm{Z}|$ & 0.9385 \\
\multirow{2}{*}{ Qtrly Real GDP, $\% \Delta$ from Qtr One Year Ago } & Democratic & $2.6614 \%$ & $-0.2733 \%$ & Prob $>|t|$ & 0.3804 \\
& Republican & $2.9347 \%$ & & Prob $>|\mathrm{Z}|$ & 0.8115 \\
$\% \Delta$ in Nonfarm Business Sector Real Output & Democratic & $0.7081 \%$ & $-0.1225 \%$ & Prob $>|t|$ & 0.4196 \\
& Republican & $0.8306 \%$ & & Prob $>|\mathrm{Z}|$ & 0.6105 \\
& Democratic & $0.7122 \%$ & $-0.1181 \%$ & Prob $>|t|$ & 0.4289 \\
& Republican & $0.8303 \%$ & & Prob $>|\mathrm{Z}|$ & 0.6681 \\
\hline
\end{tabular}

This table shows mean difference analysis for GDP growth measured as the annualized percent change from the previous quarter, GDP growth measured as the percent change from one year prior, the percent change in Nonfarm Business Sector Real Output and the percent change in Business Sector Real Output. The last column reports the $p$-value associated with a two-tailed test for the parametric $t$-test (Prob $>|t|)$ and the non-parametric Mann-Whitney test (Prob $>|Z|)$ for differences in means. ***, **, and *indicate significance at the 1, 5 and 10 percent levels, respectively. The number of observations in each sample is the same number of quarters as indicated in Table 1.

In addition to economic growth, several additional monthly economic time series are examined. Comparing the political parties that occupy the White House in Table 5, the monthly percent change in the Coincident Economic Index (CEI), Total Nonfarm Payrolls (TNFP), and Industrial Production (INDPRO) are statistically significantly higher under Democratic control versus Republican control. The changes in the Consumer Price Index (CPI) and the Producer Price Index (PPI) are also higher under Democratic administrations, while the unemployment rate is lower. However, these last three differences are generally not statistically significant. Overall, Democratic presidencies tend to see a stronger economy, higher job growth, and higher increases in productivity.

Table 6 considers the same variables but controls for which party has a majority in the Senate. The monthly percent changes in the CEI and TNFP are higher when Republicans control the Senate and these differences are generally statistically significant. INDPRO is lower when Democrats control the Senate, but the difference is not significant. Inflation, as measured by the monthly change in the CPI and PPI and the unemployment rate are all statistically significantly higher, generally at the $1 \%$ level, when Democrats control the Senate. A similar pattern is observed when the party in charge of the House is considered. As reported in Table 7, the monthly percent change in the CEI, TNFP, and INDPRO is higher when Republicans control the House, although these differences are not statistically significant. However, the level of inflation (as measured by changes in the CPI and PPI) and the unemployment rate are higher when Democrats control the House and this difference is statistically significant. In summary, changes in the Coincident Economic Index, Total Nonfarm Payrolls, and Industrial Production are generally stronger under Democratic presidents but lower under a Democratic House or Senate. Inflation and unemployment tend to be higher when Democrats control either the Senate or the House. 
Table 5: Mean Difference Analysis for Economic Variables by Presidential Political Party

\begin{tabular}{|c|c|c|c|c|c|}
\hline & $\overline{\text { Party }}$ & Mean & Difference & & \\
\hline \multirow[t]{2}{*}{$\% \Delta$ in CEI } & Democratic & $0.2036 \%$ & $0.0884 \%$ & Prob $>|t|$ & $0.0027 * * *$ \\
\hline & Republican & $0.1152 \%$ & & Prob $>|\mathrm{Z}|$ & $0.0020^{* * *}$ \\
\hline \multirow[t]{2}{*}{$\% \Delta$ in TNFP } & Democratic & $0.1630 \%$ & $0.0787 \%$ & Prob $>|t|$ & $0.0001^{* * *}$ \\
\hline & Republican & $0.0843 \%$ & & Prob $>|Z|$ & $0.0001^{* * *}$ \\
\hline \multirow[t]{2}{*}{$\% \Delta$ in INDPRO } & Democratic & $0.2416 \%$ & $0.1525 \%$ & Prob $>|t|$ & $0.0140 * *$ \\
\hline & Republican & $0.0891 \%$ & & Prob $>|Z|$ & $0.0096 * * *$ \\
\hline \multirow[t]{2}{*}{$\% \Delta$ in $\mathrm{CPI}$} & Democratic & $0.3071 \%$ & $0.0186 \%$ & Prob $>|t|$ & 0.5136 \\
\hline & Republican & $0.2885 \%$ & & Prob $>|Z|$ & $0.0458^{* *}$ \\
\hline \multirow[t]{2}{*}{$\% \Delta$ in PPI } & Democratic & $0.2736 \%$ & $0.0792 \%$ & Prob $>|t|$ & 0.3408 \\
\hline & Republican & $0.1944 \%$ & & Prob $>|Z|$ & 0.4203 \\
\hline \multirow[t]{2}{*}{ Unemployment Rate } & Democratic & $6.3671 \%$ & $-0.0167 \%$ & Prob $>|t|$ & 0.9074 \\
\hline & Republican & $6.3838 \%$ & & Prob $>|\mathrm{Z}|$ & 0.7445 \\
\hline
\end{tabular}

This table shows mean difference analysis for the percent change in the Coincident Economic Index (CEI), the percent change in Total Nonfarm Payrolls (TNFP), the percent change in Industrial Production (INDPRO), the percent change in Consumer Price Index (CPI), the percent change in the Producer Price Index (PPI), and the unemployment rate. The last column reports the p-value associated with a two-tailed test for the parametric $t$-test (Prob $>|t|)$ and the non-parametric Mann-Whitney test (Prob $>|Z|)$ for differences in means. ***, **, and * indicate significance at the 1, 5 and 10 percent levels, respectively. The number of observations in each sample is the same number of months as indicated in Table 1.

Table 6: Mean Difference Analysis for Economic Variables by Senate Political Party

\begin{tabular}{|c|c|c|c|c|c|}
\hline & Party & Mean & Difference & & \\
\hline \multirow[t]{2}{*}{$\% \Delta$ in CEI } & Democratic & $0.1306 \%$ & $-0.0623 \%$ & Prob $>|t|$ & $0.0317 * *$ \\
\hline & Republican & $0.1929 \%$ & & Prob $>|Z|$ & 0.0909* \\
\hline \multirow[t]{2}{*}{$\% \Delta$ in TNFP } & Democratic & $0.1073 \%$ & $-0.0353 \%$ & Prob $>|t|$ & $0.0448^{* *}$ \\
\hline & Republican & $0.1426 \%$ & & Prob $>|Z|$ & 0.1014 \\
\hline \multirow[t]{2}{*}{$\% \Delta$ in INDPRO } & Democratic & $0.1547 \%$ & $-0.0231 \%$ & Prob $>|t|$ & 0.7084 \\
\hline & Republican & $0.1778 \%$ & & Prob $>|Z|$ & 0.6176 \\
\hline \multirow[t]{2}{*}{$\% \Delta$ in CPI } & Democratic & $0.3381 \%$ & $0.0872 \%$ & Prob $>|t|$ & $0.0027 * * *$ \\
\hline & Republican & $0.2509 \%$ & & Prob $>|Z|$ & $0.0027 * * *$ \\
\hline \multirow[t]{2}{*}{$\% \Delta$ in PPI } & Democratic & $0.3005 \%$ & $0.1437 \%$ & Prob $>|t|$ & $0.0795 *$ \\
\hline & Republican & $0.1568 \%$ & & Prob $>|Z|$ & $0.0052^{* * *}$ \\
\hline \multirow[t]{2}{*}{ Unemployment Rate } & Democratic & $6.7085 \%$ & $0.7202 \%$ & Prob $>|t|$ & $0.0001^{* * *}$ \\
\hline & Republican & $5.9883 \%$ & & Prob $>|Z|$ & $0.0001^{* * *}$ \\
\hline
\end{tabular}

This table shows mean difference analysis for the percent change in the Coincident Economic Index (CEI), the percent change in Total Nonfarm Payrolls (TNFP), the percent change in Industrial Production (INDPRO), the percent change in Consumer Price Index (CPI), the percent change in the Producer Price Index (PPI), and the unemployment rate. The last column reports the p-value associated with a two-tailed test for the parametric t-test (Prob $>|t|)$ and the non-parametric Mann-Whitney test (Prob $>|Z|)$ for differences in means. ***, **, and * indicate significance at the 1,5 and 10 percent levels, respectively. The number of observations in each sample is the same number of months as indicated in Table 1.

Although the number of months each party controlled the presidency is equal, the number of months the U.S. economy was in a recession is quite unbalanced. As Table 8 illustrates, during the 480 months between 1977 and 2016, inclusive, the National Bureau of Economic Research determined the U.S. economy was in a recession for 56 of those months, or about $11.67 \%$ of the time. The economy was in a recession only $5 \%$ of the time (12 months) while a Democrat was president as compared to $18.33 \%$ of the time (44 months) when a Republican was president. These differences are statistically significant at the $1 \%$ level. Thus, recessions occurred significantly more often when Republicans controlled the presidency. 
However, the opposite is true when Republicans control the Senate or House. In the case of a Republican controlled Senate, the U.S. economy was in a recession for only 18 months versus 38 months for a Democratic controlled Senate. The difference is even more striking when Republicans control the House, during which the U.S. economy was in a recession for only 8 months versus 48 months for a Democratic House. The differences for the Senate and House are both statistically different at the $1 \%$ level. In summary, the economy generally does better with a Democratic President, a Republican Senate, or a Republican House. Up to this point, the impact of Democratic or Republican control of the presidency, the Senate, and the House has been considered in isolation. Tables 9, 10, and 11 examine the pairwise comparisons of all the combinations of the controlling parties of the presidency, the Senate, and the House (PSH). For example, DDD represents those times when Democrats controlled all three while RRD represents the periods when there was a Republican President, a Republican Senate, and a Democratic House. Table 9 lists the number of periods for all the combinations alphabetically. DDD and RDD each account for $20 \%$ of the period examined while RDR makes up less than $4 \%$. During the period examined, there was not a time when there was a Democratic President, a Republican Senate, and a Democratic House (DRD).

Table 7: Mean Difference Analysis for Economic Variables by House Political Party

\begin{tabular}{|c|c|c|c|c|c|}
\hline & Party & Mean & Difference & & \\
\hline \multirow[t]{2}{*}{$\% \Delta$ in CEI } & Democratic & $0.1424 \%$ & $-0.0379 \%$ & Prob $>|t|$ & 0.1836 \\
\hline & Republican & $0.1803 \%$ & & Prob $>|Z|$ & 0.4419 \\
\hline \multirow[t]{2}{*}{$\% \Delta$ in TNFP } & Democratic & $0.1214 \%$ & $-0.0050 \%$ & Prob $>|t|$ & 0.7667 \\
\hline & Republican & $0.1264 \%$ & & Prob $>|\mathrm{Z}|$ & 0.3270 \\
\hline \multirow[t]{2}{*}{$\% \Delta$ in INDPRO } & Democratic & $0.1443 \%$ & $-0.0468 \%$ & Prob $>|t|$ & 0.4354 \\
\hline & Republican & $0.1911 \%$ & & Prob $>|Z|$ & 0.9404 \\
\hline \multirow[t]{2}{*}{$\% \Delta$ in CPI } & Democratic & $0.3900 \%$ & $0.2049 \%$ & Prob $>|t|$ & $0.0001 * * *$ \\
\hline & Republican & $0.1851 \%$ & & Prob $>|Z|$ & $0.0001 * * *$ \\
\hline \multirow[t]{2}{*}{$\% \Delta$ in PPI } & Democratic & $0.3092 \%$ & $0.1670 \%$ & Prob $>|t|$ & $0.0447 * *$ \\
\hline & Republican & $0.1422 \%$ & & Prob $>|\mathrm{Z}|$ & $0.0123^{* *}$ \\
\hline \multirow[t]{2}{*}{ Unemployment Rate } & Democratic & $6.9985 \%$ & $1.3846 \%$ & Prob $>|t|$ & $0.0001^{* * *}$ \\
\hline & Republican & $5.6139 \%$ & & Prob $>|Z|$ & $0.0001 * * *$ \\
\hline
\end{tabular}

This table shows mean difference analysis for the percent change in the Coincident Economic Index (CEI), the percent change in Total Nonfarm Payrolls (TNFP), the percent change in Industrial Production (INDPRO), the percent change in Consumer Price Index (CPI), the percent change in the Producer Price Index (PPI), and the unemployment rate. The last column reports the p-value associated with a two-tailed test for the parametric $t$-test (Prob $>|t|)$ and the non-parametric Mann-Whitney test (Prob $>|Z|)$ for differences in means. ***, **, and * indicate significance at the 1, 5 and 10 percent levels, respectively. The number of observations in each sample is the same number of months as indicated in Table 1.

Table 10 details the mean percent growth in the economy using the same measures used earlier: mean GDP growth, measured both as the annualized percent change from the previous quarter and as the percent change from one year prior, the mean percent change in Nonfarm Business Sector Real Output and the mean percent change in Business Sector Real Output. Each PSH combination is listed from largest to smallest mean. The Levels columns indicate if the PSH combinations are statistically significantly different from each other using Tukey's HSD test. Levels connected by the same letter are not significantly different from each other and levels not connected by the same letter are significantly different at the $5 \%$ level. For all four measures of economic growth, a Democratic President with a Republican House and Senate (DRR) have the highest mean growth rate while a Republican President with a Democratic House and Republican Senate (RDR) have the lowest average economic growth rate. However, none of the differences in means are statistically significant at the $5 \%$ level. It is interesting to note that when the same party controls the presidency, the Senate, and the House, (DDD and RRR), the mean growth rate is ranked somewhere in the middle. By all four measures, the mean growth rate in the economy is slightly higher under RRR compared 
to DDD, although the differences are not statistically significant. From this, one could anecdotally conclude that some political gridlock is good for economic growth in the United States.

Table 8: Months in Recession

\begin{tabular}{|c|c|c|c|c|c|c|}
\hline & & $\begin{array}{l}\text { \# of Months } \\
\text { in Recession }\end{array}$ & $\begin{array}{c}\text { Mean \% of Months in } \\
\text { Recession }\end{array}$ & Difference & & \\
\hline \multirow[t]{2}{*}{ President } & Democratic & 12 & $5.00 \%$ & $(13.33 \%)$ & Prob $>$ ChiSqr & $0.0001^{* * *}$ \\
\hline & Republican & 44 & $18.33 \%$ & & & \\
\hline \multirow[t]{2}{*}{ Senate } & Democratic & 38 & $14.67 \%$ & $6.53 \%$ & Prob $>$ ChiSqr & $0.0266 * *$ \\
\hline & Republican & 18 & $8.14 \%$ & & & \\
\hline \multirow[t]{2}{*}{ House } & Democratic & 48 & $18.18 \%$ & $14.48 \%$ & Prob $>$ ChiSqr & $0.0001^{* * *}$ \\
\hline & Republican & 8 & $3.70 \%$ & & & \\
\hline
\end{tabular}

This table shows mean difference analysis for the mean percent of months the U.S. economy was in a recession during Democratic and Republican control of the presidency, Senate, and House of Representatives (House) between 1977 and 2016, inclusive. The last column reports the p-value associated with the non-parametric Friedman Rank test (Prob $>\mid$ ChiSqr $\mid)$ for differences in means. ***, **, and * indicate significance at the 1, 5 and 10 percent levels, respectively.

Table 9: Combinations of Parties in Control

\begin{tabular}{l|cc}
\hline & \# of Quarters & \# of Months \\
\hline DDD & 32 & 96 \\
DDR & 16 & 48 \\
DRR & 32 & 96 \\
RDD & 32 & 96 \\
RDR & 6 & 19 \\
RRD & 24 & 72 \\
RRR & 18 & 53 \\
\hline
\end{tabular}

This table shows the number of quarters and months for each of the possible combinations of the controlling party of the presidency, the Senate, and the House. For example, RRD represents periods with a Republican President, a Republican Senate, and a Democratic House. Between 1977 - 2016 inclusive, there was not a time when there was a Democratic President, a Republican Senate, and a Democratic House (DRD).

The monthly percent change in the Coincident Economic Index (CEI), Total Nonfarm Payrolls (TNFP), Industrial Production (INDPRO), the Consumer Price Index (CPI), the Producer Price Index (PPI) and the unemployment rate are compared for all PSH combinations in Panel A of Table 11. For both the percent change in the Coincident Economic Index and the Total Nonfarm Payrolls, a Democratic President with a Republican Senate and House (DRR) has the highest (best) mean while a Republican President with a Democratic Senate and a Republican House (RDR) has the lowest (worst).

These differences are significant at the 5\% level. When examining Industrial Production, RDR still has the worst growth rate while DDD has the best. However, these differences are not statistically significant. In Panel B of Table 11, the highest (worst) mean inflation rate, as measured by the percent change in the Consumer Price Index and the Producer Price Index, occurred when Democrats controlled the presidency, the Senate, and the House (DDD), while the lowest inflation rates were during the periods with a Republican President, a Democratic Senate, and a Republican House (RDR.) These differences are significant at the 5\% level. During the time with a Democrat in the White House and Republicans controlling both chambers of Congress (DRR), the United States had the lowest average unemployment rate (4.8469\%) while a Republican President with a Republican Senate and a Democratic House (RRD) had the highest average unemployment rate (8.1042\%). 
Table 10: Economic Growth and Pairwise Comparison of Party in Control of the Presidency, Senate and House

\begin{tabular}{|c|c|c|c|}
\hline & Party of Pres/Sen/House & Mean & Level \\
\hline \multirow[t]{7}{*}{ Qtrly Real GDP, $\% \Delta$ from Preceding Period } & DRR & $3.4656 \%$ & A \\
\hline & RRD & $3.4417 \%$ & A \\
\hline & RRR & $3.0500 \%$ & A \\
\hline & DDD & $2.8531 \%$ & A \\
\hline & DDR & $2.1625 \%$ & A \\
\hline & RDD & $2.0688 \%$ & A \\
\hline & RDR & $1.2833 \%$ & A \\
\hline \multirow[t]{7}{*}{ Qtrly Real GDP, $\% \Delta$ from QTR One Year Ago } & DRR & $3.6063 \%$ & A \\
\hline & RRD & $3.3750 \%$ & A \\
\hline & RRR & $3.0889 \%$ & A \\
\hline & DDD & $2.4938 \%$ & A \\
\hline & RDD & $2.2938 \%$ & A \\
\hline & DDR & $2.0438 \%$ & A \\
\hline & RDR & $1.2667 \%$ & A \\
\hline \multirow[t]{7}{*}{$\% \Delta$ in Nonfarm Business Sector Real Output } & DRR & $0.9980 \%$ & A \\
\hline & RRD & $0.8998 \%$ & A \\
\hline & RRR & $0.8621 \%$ & A \\
\hline & DDD & $0.8008 \%$ & A \\
\hline & DDR & $0.6728 \%$ & A \\
\hline & RDD & $0.4718 \%$ & A \\
\hline & RDR & $0.2637 \%$ & A \\
\hline \multirow[t]{7}{*}{$\% \Delta$ in Business Sector Real Output } & DRR & $0.9973 \%$ & A \\
\hline & RRD & $0.9218 \%$ & A \\
\hline & RRR & $0.8482 \%$ & A \\
\hline & DDD & $0.7916 \%$ & A \\
\hline & DDR & $0.6757 \%$ & A \\
\hline & RDD & $0.4757 \%$ & A \\
\hline & RDR & $0.2975 \%$ & A \\
\hline
\end{tabular}

This table shows mean difference analysis for GDP growth measured as the annualized percent change from the previous quarter, GDP growth measured as the percent change from one year prior, the percent change in Nonfarm Business Sector Real Output and the percent change in Business Sector Real Output for each of the possible combinations of the controlling party of the presidency, the Senate, and the House. For example, RRD represents periods with a Republican President, a Republican Senate, and a Democratic House. The number of observations in each sample is the same number of quarters as indicated in Table 9. Levels connected by the same letter in the Level column are not significantly different from each other and levels not connected by the same letter are significantly different at the 5\% level using the Tukey-Kramer test.

In summary, the economy appears to do best with a Democrat in the White House while Republicans control both the Senate and House (DRR.) A Republican President with Democrats controlling the Senate and Republicans in charge of the House (RDR) seem to be the worst combination for the economy. Table 12 shows the number of months and the mean percent of months the United States was in a recession for each PSH combination, ranked by the mean percent months in a recession. On average, the U.S. economy has been in a recession $11.67 \%$ of the time. The greatest percentage of months in a recession occurred with a Republican President, a Democratic Senate, and a Republican House (RDR). This PSH combination accounted for 19 months of the total period examined and the economy was in a recession for 6 of those months, or $31.58 \%$ of the time. The period with a Republican President and a Democratic House and Senate (RDD) accounts for the greatest number of months in a recession with 20 out of 96 total months, or 20.83\% 
of the time. There were no recessions during periods with a Democratic President and Senate with a Republican House (DDR) or a Democratic President with Republicans controlling both the Senate and House (DRR) even though these two PSH combinations made up 144 months, or 30\%, of the 40-year period examined. The mean percentage of months in a recession for both RDR and RRD are statistically higher than the mean percentage of months in a recession for DDR and DRR. As demonstrated earlier, the PSH combination of DDR appears to be better for the U.S. economy than RDR.

Table 11 Panel A: Economic Variables and Pairwise Comparison of Party in Control of President, Senate and House

\begin{tabular}{|c|c|c|c|c|}
\hline & Party of Pres/Sen/House & Mean & & Level \\
\hline \multirow[t]{7}{*}{$\% \Delta$ in CEI } & $\overline{D R R}$ & $0.2337 \%$ & $\bar{A}$ & \\
\hline & DDR & $0.1895 \%$ & A & B \\
\hline & DDD & $0.1806 \%$ & A & B \\
\hline & RRD & $0.1754 \%$ & A & B \\
\hline & RRR & $0.1527 \%$ & A & B \\
\hline & RDD & $0.0794 \%$ & & B \\
\hline & $\mathrm{RDR}$ & $-0.0363 \%$ & & B \\
\hline \multirow[t]{7}{*}{$\% \triangle$ in TNFP } & DRR & $0.1757 \%$ & A & \\
\hline & DDD & $0.1583 \%$ & A & \\
\hline & DDR & $0.1470 \%$ & A & B \\
\hline & RRD & $0.1393 \%$ & A & B \\
\hline & RRR & $0.0915 \%$ & A & B \\
\hline & RDD & $0.0710 \%$ & & B \\
\hline & RDR & $-0.0775 \%$ & & C \\
\hline \multirow[t]{7}{*}{$\% \triangle$ in INDPRO } & DDD & $0.2579 \%$ & A & \\
\hline & DRR & $0.2382 \%$ & A & \\
\hline & DDR & $0.2160 \%$ & A & \\
\hline & RRR & $0.1468 \%$ & A & \\
\hline & RRD & $0.1309 \%$ & A & \\
\hline & RDD & $0.0407 \%$ & A & \\
\hline & RDR & $0.0145 \%$ & A & \\
\hline
\end{tabular}

This table shows mean difference analysis for the percent change in the Coincident Economic Index (CEI), the percent change in Total Nonfarm Payrolls (TNFP), and the percent change in Industrial Production (INDPRO) for each of the possible combinations of the controlling party of the presidency, the Senate, and the House. For example, RRD represents periods with a Republican President, a Republican Senate, and a Democratic House. The number of observations in each sample is the same number of months as indicated in Table 9. Levels connected by the same letter in the Level column are not significantly different from each other and levels not connected by the same letter are significantly different at the 5\% level using the Tukey-Kramer test. 
Table 11 Panel B: Economic Variables and Pairwise Comparison of Party in Control of President, Senate and House

\begin{tabular}{|c|c|c|c|c|c|c|}
\hline & Party of Pres/Sen/House & Mean & \multicolumn{4}{|c|}{ Level } \\
\hline \multirow[t]{7}{*}{$\% \Delta$ in CPI } & DDD & $0.5094 \%$ & A & & & \\
\hline & RRD & $0.3465 \%$ & & B & & \\
\hline & RDD & $0.3034 \%$ & & B & C & \\
\hline & RRR & $0.2388 \%$ & & B & $\mathrm{C}$ & $\mathrm{D}$ \\
\hline & DRR & $0.1862 \%$ & & & C & $\mathrm{D}$ \\
\hline & DDR & $0.1443 \%$ & & & & $\mathrm{D}$ \\
\hline & RDR & $0.1323 \%$ & & B & C & $\mathrm{D}$ \\
\hline \multirow[t]{7}{*}{$\% \Delta$ in PPI } & DDD & $0.5728 \%$ & A & & & \\
\hline & RRR & $0.4313 \%$ & A & B & & \\
\hline & RDD & $0.2131 \%$ & A & B & & \\
\hline & RRD & $0.0858 \%$ & & B & & \\
\hline & DDR & $0.0823 \%$ & & B & & \\
\hline & DRR & $0.0702 \%$ & & B & & \\
\hline & RDR & $-0.1489 \%$ & & B & & \\
\hline \multirow[t]{7}{*}{ Unemployment Rate } & RRD & $8.1042 \%$ & A & & & \\
\hline & DDR & $7.6313 \%$ & A & B & & \\
\hline & DDD & $7.2552 \%$ & & B & & \\
\hline & RDD & $5.9125 \%$ & & & C & \\
\hline & RDR & $5.5211 \%$ & & & C & $\mathrm{D}$ \\
\hline & RRR & $5.2094 \%$ & & & & $\mathrm{D}$ \\
\hline & DRR & $4.8469 \%$ & & & & $\mathrm{D}$ \\
\hline
\end{tabular}

This table shows mean difference analysis for the percent change in the Consumer Price Index (CPI), the percent change in Produce Price Index (PPI), and the unemployment rate for each of the possible combinations of the controlling party of the presidency, the Senate, and the House. For example, RRD represents periods with a Republican President, a Republican Senate, and a Democratic House. The number of observations in each sample is the same number of months as indicated in Table 9. Levels connected by the same letter in the Level column are not significantly different from each other and levels not connected by the same letter are significantly different at the 5\% level using the Tukey-Kramer test.

As an additional analysis, the impact of the political party in control of the presidency, Senate, and House are examined by estimating the multivariate regression model:

$X_{i}=\beta_{0}+\beta_{1}$ President $[D]_{i}+\beta_{2}$ Senate $[D]_{i}+\beta_{3}$ House $[D]_{i}+\varepsilon_{i}$,

where $\mathrm{X}$ is the variable of interest, President[D] is set to 1 when the President is a Democrat and 0 otherwise, Senate[D] is set to 1 when the Senate is controlled by the Democrats and 0 otherwise, and House[D] is set to 1 when the House of Representatives is controlled by the Democrats and 0 otherwise. As shown in Table 13, the results are consistent with those found in Tables 2, 3, and 4. Economic growth is statistically weaker when the Senate is controlled by the Democrats, while the political party of the President and House do not appear to have a statistically significant impact on economic growth. 
Table 12: Pairwise Comparison of Months in Recession by Party in Control of the Presidency, Senate, and House

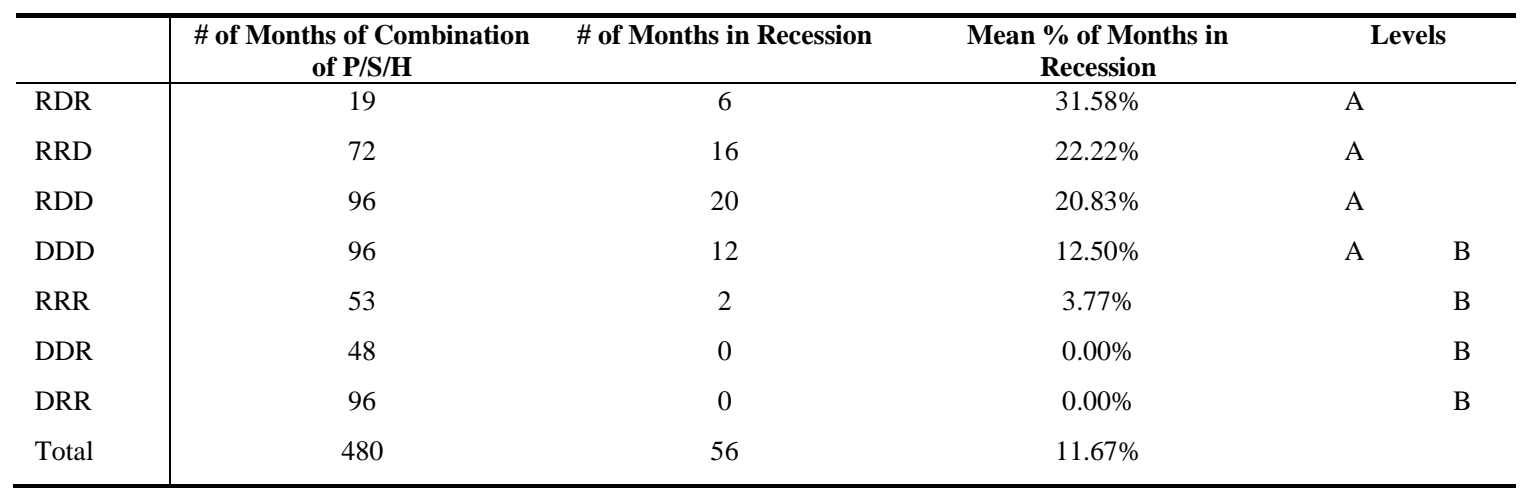

This table shows mean difference analysis for the mean percent of months the U.S. economy was in a recession for each of the possible combinations of the controlling party of the presidency, the Senate, and the House. For example, RRD represents periods with a Republican President, a Republican Senate, and a Democratic House. Levels connected by the same letter in the Level column are not significantly different from each other and levels not connected by the same letter are significantly different at the 5\% level using the Tukey-Kramer test.

The results in Table 14 are similar to those found in Tables 5, 6, and 7. The percent change in the Coincident Economic Index, the percent change in Total Nonfarm Payrolls, and the percent change in Industrial Production are each statistically greater under Democratic Presidents while the CEI, and TNFP are statistically lower under Democratic Senates. The party in charge of the House does not appear to have a significant impact on the change in these variables. Table 14 also contains evidence that inflation and unemployment are generally higher under Democratic Presidencies and Democratic Houses, while the political party in charge of the Senate does not appear to have a significant impact on these variables.

Table 15 reports the results of logistic regression model:

Recession Indicator ${ }_{i}=\beta_{0}+\beta_{1}$ President $[D]_{i}+\beta_{2}$ Senate $[D]_{i}+\beta_{3}$ House $_{D}[D]_{i}+\varepsilon_{i}$,

where the Recession Indicator is 1 for months when the U.S. economy is in a recession and 0 otherwise. President[D] is 1 when the President is a Democrat and 0 otherwise, Senate[D] is 1 when the Senate is controlled by Democrats and 0 otherwise, and House[D] is 1 when Democrats control the House of Representatives and 0 otherwise. The economy appears to be less likely to be in a recession when a Democrat is President but more likely to be in a recession when Democrats control the House. The results are consistent with those of Table 12, which showed that during the 40-year period examined, a Democrat was President for all the months the economy was not in a recession. However, Table 12 also showed that Democrats controlled the House for 48 of the 56 months the economy was in a recession. 
Table 13: Regression Results for Economic Growth on President, Senate, and House Political Party

\begin{tabular}{|c|c|c|c|}
\hline Dependent Variable $\left(\mathrm{X}_{\mathrm{i}}\right)$ & $\begin{array}{l}\text { Independent } \\
\text { Variables } \\
\end{array}$ & Coefficient & Prob $>|\mathbf{t}|$ \\
\hline \multirow[t]{4}{*}{ Qtrly Real GDP, $\% \Delta$ from Preceding Period } & Intercept $\left(\beta_{0}\right)$ & 0.0280 & $0.0001^{* * *}$ \\
\hline & President[D] $\left(\beta_{1}\right)$ & 0.0034 & 0.2059 \\
\hline & Senate[D] $\left(\beta_{2}\right)$ & -0.0062 & $0.0321 * *$ \\
\hline & House $[\mathrm{D}]\left(\beta_{3}\right)$ & 0.0030 & 0.3136 \\
\hline \multirow[t]{4}{*}{ Qtrly Real GDP, $\% \Delta$ from Qtr One Year Ago } & Intercept $\left(\beta_{0}\right)$ & 0.0279 & $0.0001^{* * *}$ \\
\hline & President $[\mathrm{D}]\left(\beta_{1}\right)$ & 0.0023 & 0.1986 \\
\hline & Senate[D] $\left(\beta_{2}\right)$ & -0.0065 & $0.0008 * * *$ \\
\hline & House $[\mathrm{D}]\left(\beta_{3}\right)$ & 0.0022 & 0.2564 \\
\hline \multirow[t]{4}{*}{$\% \Delta$ in Nonfarm Business Sector Real Output } & Intercept $\left(\beta_{0}\right)$ & 0.0077 & $0.0001^{* * *}$ \\
\hline & President[D] $\left(\beta_{1}\right)$ & 0.0014 & 0.1241 \\
\hline & Senate[D] $\left(\beta_{2}\right)$ & -0.0018 & $0.0586 * *$ \\
\hline & House[D] $\left(\beta_{3}\right)$ & 0.0006 & 0.5386 \\
\hline \multirow[t]{4}{*}{$\% \Delta$ in Business Sector Real Output } & Intercept $\left(\beta_{0}\right)$ & 0.0077 & $0.0001 * * *$ \\
\hline & President $[\mathrm{D}]\left(\beta_{1}\right)$ & 0.0013 & 0.1299 \\
\hline & Senate[D] $\left(\beta_{2}\right)$ & -0.0018 & $0.0501^{*}$ \\
\hline & House $[\mathrm{D}]\left(\beta_{3}\right)$ & 0.0006 & 0.5151 \\
\hline
\end{tabular}

This table shows regression results based on equation (2). President[D] is 1 when the President is a Democrat and 0 otherwise, Senate[D] is 1 when the Senate is controlled by Democrats and 0 otherwise, and House[D] is 1 when Democrats control the House of Representatives and 0 otherwise. The last column reports the p-value. ***, **, and * indicate significance at the 1, 5 and 10 percent levels, respectively. The number of observations in each regression is the same number of quarters as indicated in Table 1.

Table 14: Regression Results for Economic Variables on President, Senate, and House Political Party

\begin{tabular}{l|lcl}
\hline Dependent Variable $\left(\mathbf{X}_{\mathbf{i}}\right)$ & Independent Variables & Coefficient & Prob $>|\mathbf{T}|$ \\
\hline$\% \Delta$ in CEI & Intercept $\left(\beta_{0}\right)$ & 0.0016 & $0.0001^{* * *}$ \\
& President[D] $\left(\beta_{1}\right)$ & 0.0006 & $0.0006^{* * *}$ \\
& Senate[D] $\left(\beta_{2}\right)$ & -0.0005 & $0.005^{* * *}$ \\
$\% \Delta$ in TNFP & House[D] $\left(\beta_{3}\right)$ & 0.0002 & 0.3178 \\
Intercept $\left(\beta_{0}\right)$ & 0.0012 & $0.0001^{* * *}$ \\
& President[D] $\left(\beta_{1}\right)$ & 0.0005 & $0.0001^{* * *}$ \\
$\% \Delta$ in INPRO & Senate[D] $\left(\beta_{2}\right)$ & -0.0004 & $0.0002^{* * *}$ \\
& House[D] $\left(\beta_{3}\right)$ & 0.0003 & 0.0057 \\
$\% \Delta$ in CPI & Intercept $\left(\beta_{0}\right)$ & 0.0017 & $0.0001^{* * *}$ \\
& President[D] $\left(\beta_{1}\right)$ & 0.0008 & $0.0128^{* *}$ \\
& Senate[D] $\left(\beta_{2}\right)$ & -0.0003 & 0.3784 \\
& House[D] $\left(\beta_{3}\right)$ & 0.0002 & 0.6800 \\
& Intercept $\left(\beta_{0}\right)$ & 0.0029 & $0.0001^{* * *}$ \\
& President[D] $\left(\beta_{1}\right)$ & 0.0005 & $0.0019^{* * *}$ \\
& Senate[D] $\left(\beta_{2}\right)$ & -0.0001 & 0.4055 \\
& House[D] $\left(\beta_{3}\right)$ & 0.0012 & $0.0001^{* * *}$ \\
& Intercept $\left(\beta_{0}\right)$ & 0.0022 & $0.0001^{* * *}$ \\
& President[D] $\left(\beta_{1}\right)$ & 0.0007 & 0.1458 \\
Unemployment Rate & Senate[D] $\left(\beta_{2}\right)$ & 0.0002 & 0.6868 \\
& House[D] $\left(\beta_{3}\right)$ & 0.0010 & $0.0551^{*}$ \\
& Intercept $\left(\beta_{0}\right)$ & 0.0630 & $0.0001^{* * *}$ \\
& President[D] $\left(\beta_{1}\right)$ & 0.0022 & $0.0021^{* * *}$ \\
& Senate[D] $\left(\beta_{2}\right)$ & 0.0001 & 0.8499 \\
& House[D] $\left(\beta_{3}\right)$ & 0.0075 & $0.0001^{* * *}$ \\
\hline
\end{tabular}

This table shows regression results based on equation (2). President[D] is a dummy variable of 1 when the President is a Democrat and 0 otherwise, Senate $[D]$ is 1 when the Senate is controlled by Democrats and 0 otherwise, and House [D] is 1 when Democrats control the House of Representatives and 0 otherwise. The last column reports the p-value. ***, **, and * indicate significance at the 1, 5 and 10 percent levels, respectively. The number of observations in each regression is the same number of months as indicated in Table 1. 
The above analysis is limited in some ways. One limitation is due to policy lags. Each first term president inherits the economy of their predecessor. Any policy changes a new president implements to affect the economy may take time to have an impact. Thus, it is difficult to disentangle the lingering impact of the previous administration's economic policies from the effects of the policies of the new administration. For example, President Obama took office while the economy was in a recession. According to the NBER, the recession officially ended 6 months later in June 2009. Did the recession end due to President Obama's economic policies? Or would the recession have ended anyway because of policies put in place during the George W. Bush administration? Or did the policies of both administrations help stabilize the economy? It is impossible to truly know. Another limitation is due to the issue of data synchronization. The economic data used in this study are either month- or quarter-end. However, every four years a President's term typically begins on January $20^{\text {th }}$. Thus, economic results for the first month of a president's term are "credited" to the political affiliation of the person taking office on January $20^{\text {th }}$. This is less of an issue in the Senate and House as both generally begin their terms on January $3^{\text {rd }}$ every other year.

\section{CONCLUDING COMMENTS}

Earlier studies have examined the relationship between the President's political party and the performance of financial and economic variables. Some have also examined the impact of having the same political party controlling the presidency, the Senate, and the House of Representatives. This paper extends the current literature by examining the impact of all combinations of the political party in control of the White House and both chambers of Congress. Past economic growth is not significantly different under Republican and Democratic presidential administrations. Nor does the party that controls the House of Representatives appear to have a significant impact on economic growth. However, growth has been strongest when Republicans control the Senate.

Table 15: Logistic Regression Results for Recession Indicator on President, Senate, and House Political Party

\begin{tabular}{l|lcl}
\hline Dependent Variable $\left(\mathbf{X}_{\mathbf{i}}\right)$ & Independent Variables & Coefficient & Prob $>|\mathbf{T}|$ \\
\hline Recession Indicator & Intercept $\left(\beta_{0}\right)$ & -2.5149 & $0.0001^{* * *}$ \\
& President[D] $\left(\beta_{1}\right)$ & -0.6379 & $0.0005^{* * *}$ \\
& Senate[D] $\left(\beta_{2}\right)$ & 0.2501 & 0.1392 \\
& House[D] $\left(\beta_{3}\right)$ & 0.6298 & $0.0029 * * *$
\end{tabular}

This table shows regression results based on equation (2). The Recession Indicator is 1 for months when the U.S. economy is in a recession and 0 otherwise. President [D] is a dummy variable of 1 when the President is a Democrat and 0 otherwise, Senate[D] is 1 when the Senate is controlled by Democrats and 0 otherwise, and House[D] is 1 when Democrats control the House of Representatives and 0 otherwise. The last column reports the p-value. ***, **, and * indicate significance at the 1,5 and 10 percent levels, respectively. The number of observations in each regression is the same number of months as indicated in Table 1.

Other economic measures, such as the Coincident Economic Index, Total Nonfarm Payrolls, and Industrial Production grow faster under Democratic Presidents while higher inflation and unemployment are observed when Democrats control the Senate or House. Republicans occupy the White House during a significantly greater number of months when the economy is in a recession. The same is true when Democrats have a majority in the Senate or House of Representatives. The U.S. economy has the strongest performance under the combination of a Democratic President with a Republican controlled Senate and House of Representatives. During the months this combination was in power, the United States did not experience a recession. At the other extreme, economic performance is generally the poorest under a Republican President with a Senate controlled by the Democrats and a House controlled by Republicans. When the same party controls the presidency, the Senate, and the House, the economic results are average. It can be concluded that certain types of political gridlock are beneficial to the U.S. economy. As discussed previously, this study has some limitations due to data synchronization issues and policy lags. Future 
research could address these issues. Future research can also examine the impact of the degree of control in the Senate and House. For example, during the $95^{\text {th }}$ Congress $(1977-1979)$, the Senate was split between 61 Democrats, 38 Republicans, and 1 Independent that caucused with the Democrats. This level of control may have a different impact on economic growth than when the Senate is more closely split, like the $115^{\text {th }}$ Congress (2017-2019) when Republicans in the Senate held 51 seats. Finally, although much research has been done on the impact of the political party of the President on financial market returns, few have looked at the role of Congress. Previous studies that have generally treat Congress as a single entity rather than two distinct chambers. None appear to have taken the approach in this study and examined all the combinations of the political parties in control of the White House, the Senate, and the House and the impact of those combinations on various financial market returns in the U.S.

\section{REFERENCES}

Abidin, S., Old, C., \& Martin, T. (2010) "Effects of New Zealand General Elections on Stock Market Returns,” International Review of Business Research Papers, 6(6), 1-12.

Adjei, F., \& Adjei, M. (2017) “Political Cycles, Investor Sentiment, and Stock Market Returns,” Journal of Finance and Economics, 5(1), 1-10.

Belo, F., Gala, V. D., \& Li, J. (2013) Government Spending, Political Cycles, and the Cross Section of Stock Returns,” Journal of Financial Economics, 107(2), 305-324.

Beyer, S. B., Jensen, G. R., \& Johnson, R. R. (2006), “Gridlock’s Gone, Now What?,” Financial Analysts Journal, 62(5), 21-28.

Beyer, S. B., Jensen, G. R., \& Johnson, R. R. (2008), “The Presidential Term,” The Journal of Portfolio Management, 34(2), 135-142.

Blinder, A. S., \& Watson, M. W. (2016), "Presidents and the US Economy: An Econometric Exploration,” American Economic Review, 106(4), 1015-1045.

Brown, G. (1992), The 1992 Election: Millbrook Press, Incorporated.

Conover, W. (1999), Practical Nonparametric Statistics, John Wiley \& Sons. INC, New York.

Fair, R. C. (1978), “The Effect of Economic Events on Votes for President,” The Review of Economics and Statistics, 159-173.

Fair, R. C. (1982), “The Effect of Economic Events on Votes for President,” The Review of Economics and Statistics, 322-325.

Fair, R. C. (1988), “The Effect of Economic Events on Votes for President: 1984 update,” Political Behavior, 10(2), 168-179.

Herbst, A. F., \& Slinkman, C. W. (1984), “Political-Economic Cycles in the US Stock Market,” Financial Analysts Journal, 40(2), 38-44.

Hibbs, D. A. (1977), "Political Parties and Macroeconomic Policy,” American Political Science Review, 71(4), 1467-1487. 
Johnson, R. R., Chittenden, W. T., \& Jensen, G. R. (1999), "Presidential Politics, Stocks, Bonds, Bills, and Inflation,” The Journal of Portfolio Management, 26(1), 27-31.

Jones, S. T., \& Banning, K. (2009), “US Elections and Monthly Stock Market Returns,” Journal of Economics and Finance, 33(3), 273.

Kräussl, R., Lucas, A., Rijsbergen, D. R., van der Sluis, P. J., \& Vrugt, E. B. (2014), "Washington Meets Wall Street: A Closer Examination of the Presidential Cycle Puzzle,” Journal of International Money and Finance, 43, 50-69.

Lamb, R. P., Ma, K., Pace, R. D., \& Kennedy, W. F. (1997), “The Congressional Calendar and Stock Market Performance,” Financial Services Review, 6(1), 19-25.

Liston, D. P., Chong, G., \& Bayram, S. G. (2014), “The Impact of Political Variables on Stock Returns and Investor Sentiment,” Journal of Business and Behavioral Sciences, 26(1), 176.

Ruxton, G. D. (2006), “The Unequal Variance t-test is an Underused Alternative to Student's t-test and the Mann-Whitney U test,” Behavioral Ecology, 17(4), 688-690.

Santa-Clara, P., \& Valkanov, R. (2003), “The Presidential Puzzle: Political Cycles and the Stock Market,” The Journal of Finance, 58(5), 1841-1872.

Sturm, R. R. (2016), “Is There a Presidential Election Cycle in Firm Financials?,” Review of Pacific Basin Financial Markets and Policies, 19(02), 1650010.

Sy, O., \& Al Zaman, A. (2011), “Resolving the Presidential Puzzle,” Financial Management, 40(2), 331355.

Welch, B. L. (1951), “On the Comparison of Several Mean Values: An Alternative Approach,” Biometrika, 38(3-4), 330-336.

Wisniewski, T. P. (2016), "Is There a Link Between Politics and Stock Returns? A Literature Survey," International Review of Financial Analysis, 47, 15-23.

Wong, W.-K., \& McAleer, M. (2009), "Mapping the Presidential Election Cycle in US Stock Markets,” Mathematics and Computers in Simulation, 79(11), 3267-3277.

\section{ACKNOWLEDGEMENT}

Thank you to the editor and two anonymous reviewers for their insightful and helpful comments.

\section{BIOGRAPHY}

William Chittenden is the Associate Dean for Graduate Programs in the McCoy College of Business at Texas State University. His research appears in journals such as Journal of Portfolio Management, Journal of Investing, and Financial Review. 